of the load to which they have learned to adapt themselves, made stronger, or are they left stagnated because the stimulus which has been prompting them to their abnormal action has been removed?

'Lo smoke tinte or four cigars in one day would probably kill a min who was not accustomed to its use, but the system of the habitual user of tobaceo has become so gradually saturated that it, like the system of the arsenicophagy is able to stand the strain. In the case of the arsenic eater instant withdrawal of the poison is sudden death.

Just why the desire for the narcotic stops during sickness, and immediately upon the receipt of injury, is unexplainable. May it not be the fact that the abnormal sedation which the tcbacco has been producing gives way to unbalance, irregularity in functions, and destructive action, upon the withdrawal of the narcotics? Is it just possible that in sickness and injuries where desire for tobacco has been lost, that some preparation of tobace should be regularly administered hypodermically:

J. L. TricY.

\section{Regarding Christian Science.}

Chicago, Sept. 12, 1901.

I'o the Editor:-In THE Journal of July 27 was published what was supposed to be "a sample of Christian Science," "a prayer for a dyspeptic, drawn up by $\mathrm{Mr}$. Hazzard, president of the New York School of Primitive and Practical Christian Science." Please permit me to state through your columns that the gentleman mentioned is not a Christian Scientist, his school is not a Christian Science school, the prayer attributed to him is not a Christian Science prayer, and the publication to which it is credited is not a Christian Science publication. Any deductions, therefore, which might be drawn as to the teach ings of Christian Science from the "prayer for a dyspeptic" must be erroneous. Archibald McLellax.

\section{Book 2Totices.}

La Peste Bubonique dans la Republique Argentine at aia Paraguay Epidémies de 1899-1900. Rapport Présenté au Départment National D'Hygiène par les Docteurs Luis Agote et A. J. Medina, Inspecteurs délégués du Gouvernement Argentin. Paper. Pp. 298. Buenos Aires: Felix Lajouane. 1901.

This report of the National Department of Hygiene of Ar gentina is an evidence of the thorough appreciation of sanitary questions in that South American Republic. The authors give the history of the introduction and course of the disease in succession into Asuncion, Rosario and Buenos Aires, discuss the local conditions in each place that favored its development, devote chapters to treatment and prophylaxis and conclude with an appendix giving reports of cases. They endorse serum therapy as giving better results in the cases in which it has been employed than other methods of treatment, and the accidents or inconveniences following its use slight. They do not, however, unreservedly hold with Haflkine that serum immunization renders needless other prophylactic measures. Where the serum treatment was impossible in these eities the treatment was largely symptomatic-balneotherapy, cardiac tonics, anti-spasmodics, intestinal disinfectants, ete. Incision of the buboes was practiced, and bleeding was found occasionally of value. The work is a valuable contribution to the not yet too ample scientific literature of this recently recrudescing pest of former times.

Transactions of the Vermont State Medical Society, 1900. Published by the Society. Cloth. Pp. 195. Free Press Association, Burlington. 1901.

The Secretary calls attention to the fact that while 15 or 20 new members are added each year, the total enrolment remains practically the same on account of those who are dropped for non-payment of dues. The membership is given as 219, although how many are back in their dues three years ia not stated. There are about 600 regular physicians in the Statu, hence only about one-third are active members of their State Society. The report of the committee on reorganization is an excellent one and contains recommendations, which, if adopted, can not but be a benefit to the profession of Vermont. In the report of the delegates to examine the graduates of the medical department of Dartmouth College, we are informed that the temperature of that day was 143 degrees below zero-rather cool certainly. The volume contains twelve papers, besides the reports, obituaries, ete.

The Office Treatment of Rectal Diseases Explained and Simplified. Being an Exposition of the Treatment of all Those Diseases, Both Medical and Surgical, of the Rectum, Anus and Sigmoid Flexure, the Cure of which May Be Accomplished Without Surgical Anesthesia. Illustrated. By Rufus D. Mason, M.D., Omaha, Neb., Professor of Rectal and Pelvic Surgery in the John A. Creighton Medical College. Cloth. Pp. 83. Price, \$1.50. Omaha: E. B. Festner. 1001.

The author does not attempt to cover the field of rectal diseases, but only those conditions that are liable to be met by the general practitioner. As such the book is to be commended.

A Hand-Book of Genito-Uurinary Surgery and Venereal DisEASEs. By G. M. Phillips, M.D., Professor of Tenito-Urinary Surgery and Venereal Diseases, Barnes Medical College. Il lustrated by Half-tone Cuts and Special Drawings by $\mathbf{L}$. Crusius, M.D. Cloth. Pp. 313. Price, $\$ 2.00$. St. Louis, Mo.; Lewis S. Matthews \& Co. 1900.

The subjects are treated clearly and concisely. The half tones and drawings are unusually good and instructive. For the student and practitioner it will be found a convenient reference book.

\section{Ritiscellany.}

San Francisco Plague Report, Fortieth Verified Death.

Lee Mon Chong, male, aged 40 years, a cigarmaker by occupation, died on Aug. 30, 1901.

Autopsy.-Body of a Chinese male, fairly well nourished; rigor mortis not present; body still warm, pupils moderately dilated, scleræ not injected. Glandular enlargement well marked in left inguinal region, slight enlargement in right axilla; no local lesion to account for enlargement. Two small ecchymotic spots over bubo in the groin, lividity not marked, slight on dependent parts. Upon incising the bubo, a bloody hemorrhagic nuid exuded; the glands were seen to be enlarged, injected, and surrounding tissues edematous. Smears from the gland, stained with carbol-thionin, showed numerous bipolar staining bacilli.

Abdominal Incision.-Subcutaneous fat was moderately abundant; subcutaneous vessels injected; left abdominal muscles infiltrated. Intestines were slightly distended, moist and glistening, showing a number of dark areas, probably submucous hemorrhages. Little or no fluid was in the abdominal cavity; appendix normal.

Diaphragm, attachment, right, 5th rib. Left, 4 th interspace. Lungs met in median line but collapsed anteriorly. Left slightly adherent at apex.

Pericardium.-Area was about normal in extent, contains about 10 c.c. of clear yellowish fluid.

Heart.-Surface was covered with fat; vessels slightly in jected; heart muscle soft and flabby. Ventricles full of fluid blood; valves normal. Numerous plaques on surface of aorta; coronary openings free. Heart muscle was pale and in some places evidence of fatty change.

Lungs.-Left lung pits on pressure and crepitates throughout. Pressure causes serum and air to exude from cut surface. No nodules. Lung appears normal except for edema. In the right lung, middle and upper lobes pit and crepitate throughout except at the site of an old tubercular scar at apex. The upper and anterior part of the lower lobe is somewhat firmer than normal, but crepitates, especially about the border. The pleura still glistens, color purplish, interspaced with dark 